\title{
The diagnosis and treatment of penile fracture: our 19-year experience
}

\author{
Penis kırığının tanı ve tedavisi: 19 yıllık deneyim
}

\author{
Abdullah GEDİK, Devrim KAYAN, Sait YAMİş, Yakup YILMAZ, Kamuran BİRCAN
}

\section{BACKGROUND}

The aim of this study was to retrospectively evaluate our approach to the diagnosis and treatment of penile fracture.

\section{METHODS}

We retrospectively evaluated the results of 107 patients with penile fracture treated in our clinic between January 1990 and January 2009. Patient age, etiology of each fracture, history, physical examination results, radiologic findings, type of treatment, and postoperative complications were recorded. In 5 cases cavernosography was performed and in 8 cases retrograde urethrography.

\section{RESULTS}

The most common etiologies of penile fracture were coitus and manually bending the penis for detumescence. Diagnoses were made based on history and physical examination in 102 patients and cavernosography in 5 patients. In order to evaluate urethral injury in 8 cases, retrograde urethrography was performed. Rupture was repaired surgically in 101 patients, but 6 patients were treated conservatively. Among the 6 conservatively treated patients, 3 developed penile curvature 6 months post-treatment; no complications occurred in the surgically treated patients.

\section{CONCLUSION}

Cavernosography should be performed only when history and physical examination are insufficient for diagnosis, and retrograde urethrography should be performed when urethral injury is suspected. In order to prevent the development of penile curvature and to ensure rapid recovery, early surgical repair is advised.

Key Words: Cavernosography; conservative treatment; penile fracture; surgical treatment.

\section{$\boldsymbol{A M A C}$}

Bu çalışmada, penis kırıkların tanı ve tedavisine yaklaşımlar retrospektif olarak değerlendirildi.

\section{GEREÇ VE YÖNTEM}

Ocak 1990 ile Ocak 2009 tarihleri arasında kliniğimize penis kırığı nedeniyle başvuran 107 hasta retrospektif olarak değerlendirildi. Hastaların yaşı, kırığın nedeni, kırığın oluş zamanı, fiziksel inceleme bulguları, radyolojik bulgular, uygulanan tedavi şekli ve ameliyat sonrası komplikasyonlar kaydedildi. Beş hastaya kavernozografi ve 8 hastaya retrograd üretrografi yapıldı.

\section{BULGULAR}

Cinsel ilişki ve uygunsuz ortamda erekte peniste detümesansı sağlamak için elle bükme penis kırığının en sık nedenleri olarak bulundu. Tanı 102 hastada anamnez ve fiziksel incelemeyle kondu. Kavernozografi 5 hastada yapıldı. Üretral yaralanma düşünülen 8 hastaya retrograd üretrografi yapıldı. Yırtıklar 101 hastada cerrahi olarak onarıldı, 6 hastaya ise konservatif tedavi yapıldı. Ameliyattan sonraki 6. ayda yapılan kontrollerde konservatif tedavi yapılan 6 hastanın 3'ünde penil kurvatur gelişirken cerrahi yapılan hastalarda hiçbir komplikasyon gelişmedi.

\section{SONUÇ}

Anamnez ve fiziksel inceleme ile kesin tanı konulamayan hastalarda kavernozografi, üretra yaralanması şüphesi olanlara ise üretrografi yapılmalıdır. Penis kırığının erken cerrahi onarımı penis kurvatur gelişimini önlemek ve hızlı iyileşmeyi sağlamak için önerilmektedir.

Anahtar Sözcükler: Kavernozografi; konservatif tedavi; penil k1rik; cerrahi tedavi. 
Penile fracture is the rupture of the tunica albuginea surrounding the corpus cavernosum. Its etiology is generally blunt trauma that occurs while the penis is erect. Manually bending an erect penis, some forms of coitus, masturbation, and falling out of bed can cause penile fracture ${ }^{[1,2]}$ Anamnesis and physical examination are the most important diagnostic tools. Anamnesis typically includes sudden detumescence and ecchymotic swelling of the penis following a cracking sound while the penis is erect. ${ }^{[3]} \mathrm{A}$ large penile hematoma can be seen on the physical examination. The hematoma can sometimes spread to the scrotum and pubic area, and generally the penis deviates to the opposite side. Anamnesis and physical examination are generally adequate for diagnosis, but if these two methods are insufficient, then cavernosography becomes necessary for the diagnosis. ${ }^{[4,5]}$

Sometimes corpus spongiosum and urethral injury are seen as adjacent injuries. It was reported that adjacent urethral injury is seen in $10 \%-33 \%$ of penile fractures, and when present, gross hematuria or urethrorrhagia with voiding difficulty are additional clinical findings. ${ }^{[6,7]}$ Retrograde urethrography is necessary for the diagnosis of urethral injury.

\section{MATERIALS AND METHODS}

All cases of penile fracture that presented to our hospital between January 1990 and January 2009 were retrospectively evaluated. The etiological factors, elapsed time from trauma to presentation, size and location of penile hematomas, penile deviation, urethrorrhagia, and the location and size of ruptures were recorded.

When the patient history and physical examination were insufficient for diagnosing penile fracture, the diagnosis was confirmed by cavernosography. In patients with microscopic or gross hematuria with or without urethrorrhagia retrograde urethrography was performed to confirm urethral injury.

In surgically treated patients, wide-spectrum antibiotics were prophylactically administered. Urethral Foley catheters were placed in all patients intraoperatively, and elastic bandages with light pressure were applied in all patients postoperatively. For conservative treatment, bed rest, elastic bandages, penoscrotal elevation, and prophylactic antibiotics were used. All patients were followed up at three and six months post-treatment.

\section{RESULTS}

All 107 patients presented to the hospital due to penile pain, penile ecchymotic swelling following sudden detumescence, or following blunt trauma to an erect penis. Mean age of the patients was $28 \pm 11$ years (range: 17-56 years). The most common types of trauma were coitus and manually bending the erect penis. The types of trauma that caused penile fracture are summarized in Table 1.

The mean elapsed time from trauma to presentation to hospital was $6 \pm 4$ hours (range: 1-24 hours). On the physical examination, urethrorrhagia was observed in 2 patients and localized hematoma was seen in 5 patients. Large hematomas caused penile deviation in 73 patients. In 29 patients, there was a large hematoma extending to the scrotum and pubic area. It was possible to palpate the rupture in 83 patients, but palpation was not possible in 19 patients because of large hematomas and severe pain. In the remaining 5 patients with localized hematomas (they did not describe hearing a cracking sound), cavernosography was performed to observe the rupture and diagnose penile fracture.

In 6 patients with a microscopic hematuria and in 2 patients with urethrorrhagia, retrograde urethrography was performed in order to determine if there was adjacent urethral and corpus spongiosum injury. Two patients had incomplete urethral injury and urethrorrhagia, but 6 patients with a microscopic hematuria did not have urethral injury.

With the exception of the 8 patients that underwent urethrography and the 5 that underwent cavernosography, no additional diagnostic imaging was performed.

Table 1. Etiological factors of penile fracture according to patient reports

\begin{tabular}{lc}
\hline Etiology & Number of Patients \\
\hline Coitus & $46(43 \%)$ \\
Manually bending the penis & $26(24.3 \%)$ \\
Rolling over in bed during sleep & $23(21.5 \%)$ \\
Masturbation & $6(5.6 \%)$ \\
Falling on an erect penis & $3(2.8 \%)$ \\
No explanation & $3(2.8 \%)$ \\
Total & $107(100 \%)$ \\
\hline
\end{tabular}

Table 2. Clinical findings of surgically repaired patients

$\mathrm{n}$

Localization of the lesion

Left corpus cavernosum

$55(54.5 \%)$

Right corpus cavernosum

$42(41.6 \%)$

Both corpora cavernosa

$4(3.9 \%)$

Length of rupture $(\mathrm{cm})$

$\begin{array}{lc}0.5-1 & 36(35.7 \%) \\ 1-2 & 61(60.4 \%) \\ 2-4 & 4(3.9 \%) \\ \text { tal number of patients } & 101(100 \%)\end{array}$

Total number of patients

$01(100 \%)$

Adjacent injuries

Urethra and corpus spongiosum $\quad 2(1.87 \%)$ 
In 101 of the 107 patients, surgical repair was performed under spinal anesthesia. The clinical findings of these 101 patients are summarized in Table 2.

In 87 patients, a subcoronal circular incision was used, whereas in 14 patients in whom it was possible to palpate the rupture, a semicircular incision was made over the rupture. Following the evacuation of the hematoma, the rupture in the cavernosal body was sutured with $2 / 0$ interrupted Vicryl sutures. In patients with adjacent urethral injury, the urethra was repaired with 4/0 interrupted Vicryl sutures. No drainage was necessary in any of the cases. All catheters placed preoperatively were removed the following day, except in 2 patients with urethral injury, in which case the catheter was removed 3 weeks postoperatively after performing pericatheter urethrography to determine patency of the urethra. All patients were discharged the day after catheter removal and were advised to refrain from coitus for 6 weeks.

Mean length of hospitalization in the surgically treated patients was 1.2 days (range: 1-4 days). No early postoperative complications were seen in any of the patients. Conservative treatment was administered in 3 patients who refused surgery and in 3 patients with minimal extravasation in cavernosography. Mean length of hospitalization in the conservatively treated patients was 5 days (range: 4-7 days).

In all, $89(88 \%)$ of the surgically treated patients and $6(100 \%)$ of the conservatively treated patients presented for the three-month follow-up, while 76 $(75 \%)$ and $4(66 \%)$, respectively, presented for the sixmonth follow-up.

At the three-month follow-up of the surgical patients, $18(17.8 \%)$ complained of slight loss of sensation in the penis and in the glans, which had completely resolved at the six-month follow-up. At the three-month follow-up of the conservatively treated patients, 2 of the 3 patients who refused surgery and 1 of the 3 patients with minimal extravasation reported minor pain and penile curvature of less than 30 degrees, which were not problematic; at the six-month follow-up, none of the patients was experiencing pain, but penile curvature persisted.

\section{DISCUSSION}

Penile fracture is a rare urologic emergency. It is the rupture of the tunica albuginea of the corpus cavernosum, which generally develops after blunt trauma while the penis is erect. The tunica albuginea is $2 \mathrm{~mm}$ thick in a flaccid penis, but decreases to $0.25 \mathrm{~mm}$ during an erection, and a sudden increase in intracorporeal pressure due to blunt trauma during an erection could easily result in rupture ${ }^{[4]}$ According to hospital statistics in the United States, the incidence of penile fracture is $1 / 175,000 \cdot{ }^{[8]}$ In total, 1,331 penile fracture cases were reported in 183 papers between 1935 and 2001, and most were reported from countries of the Mediterranean and Middle East. Coitus as the etiological factor of penile fracture was reported in $33 \%$ and $60 \%$ of cases. ${ }^{[9,10]}$ Zargooshi $^{[11]}$ published the largest series of penile fractures (172 cases) and reported that in $69.1 \%$ of cases, the etiological factor was manually bending an erected penis for detumescence while in $8.1 \%$ of cases, the etiological factor was coitus. Özen et al., ${ }^{[12]}$ Asgari et al. ${ }^{[13]}$ and el-Sherif et al. ${ }^{[14]}$ reported that penile fractures were caused by manually bending the penis for detumescence in $64 \%$ of cases ( 16 of 25 patients), $78 \%$ of cases ( 25 of 32 patients), and $61.9 \%$ of cases (13 of 21 patients), respectively.

The most frequent etiological factor in the present series was coitus $(43 \%)$. The incidence of manually bending the penis for detumescence in the present series was $24.3 \%$ (26 patients). The reported incidence of the various etiological factors for penile fracture varies because patients do not always accurately report the cause, probably due to embarrassment. One of our patients from a rural area presented to a primary care center and reported that he had suffered a scorpion bite on his penis. He was treated with scorpion antiserum prior to being referred to our clinic. Even after repairing his $1.5-\mathrm{cm}$ rupture, he still did not reveal the actual cause of his penile fracture.

In the present study, 3 patients refused to report the cause of fracture. Possible etiological factors other than coitus and manual bending were turning over during sleep, falling out of bed, masturbation, and being kicked by an animal. Despite the difficulty in determining the etiological factor, the diagnosis of penile fracture is not difficult. Patients complain about penile pain, deviation and ecchymotic swelling following sudden detumescence of the penis, accompanied by a cracking sound. Some authors suggest that cavernosography should be routinely performed in order to differentiate penile fracture from dorsal vein rupture, ${ }^{[15]}$ but one should always consider that anaphylactic reactions can occur in response to use of opaque material, and extravasation of opaque material could result in fibrosis. During cavernosography of large hematomas, determination of the length of rupture can sometimes be limited and cause false-negative results. We performed cavernosography in 5 of our patients with small hematomas, as they were not sure if they heard a cracking sound. In 2 of these patients, the extravasation was quite large and we repaired the rupture surgically. The other 3 patients with minimal extravasation were treated conservatively.

It is reported that urethral injury could be an adjacent injury in $10 \%-33 \%$ of penile fractures. ${ }^{[6,7]}$ The incidence of adjacent urethral injury was low in reports 
from Iran, Persian Gulf countries and Japan (0-3\%), but high in reports from European countries $(20 \%$ $38 \%)^{[11]}$ This variation in the incidence of urethral injury is probably due to differences in etiological factors between countries. The incidence of urethral injury in the present study was $1.8 \%$ ( 2 patients), and both cases had urethrorrhagia and difficulty voiding. We performed retrograde urethrography in these 2 patients as well as in patients with microscopic hematuria. In the present study, urethral injury was diagnosed in only 2 patients who had urethrorrhagia and difficulty voiding; therefore, we suggest performing retrograde urethrography only in patients with difficulty voiding and/or urethrorrhagia, and not in those with only microscopic hematuria.

Early reports suggested that penile fractures should be treated conservatively with elastic bandages, cold compress, antibiotics, fibrinolytics, and anti-inflammatory drugs; however, with long-term follow-up, it was observed that conservatively treated patients experienced complications such as penile pain, penile curvature, arteriovenous fistulas, and erectile dysfunction, at the rate of $10 \%-53 \% \cdot{ }^{[9,16,17]}$ Muentener et al. ${ }^{[3]}$ compared surgical and conservative treatments and reported success rates of $92 \%$ and $59 \%$, respectively.

We treated 6 of our patients conservatively and during the long-term follow-up, 3 of them developed penile curvature of less than 30 degrees and penile pain, which did not interfere with coitus. The length of hospitalization was also longer among the conservatively treated patients. Thus, based on our results, we no longer advise conservative treatment because penile curvature developed even in our patients with minimal extravasation.

In the treatment of penile fractures, early surgical repair is generally preferred in order to avoid complications such as penile curvature, the development of fibrotic plaques and painful erection. Early surgical repair might also preserve sexual function and decrease the length of hospitalization. ${ }^{[9,11,13]}$

For surgical repair, we primarily used subcoronal circular incision. This incision facilitates successful repair of the rupture and evaluation of the other cavernosal body and corpus spongiosum. Intraoperative examination with this type of incision helped us to indentify overlooked adjacent injuries. In some of our patients, we used a semicircular incision over the rupture line when it could be clearly palpated. It is possible to successfully repair the rupture with this type of incision, but this incision is inadequate for evaluating the other cavernosal body and corpus spongiosum. Despite the fact that it is easy to change the semicircular incision to a circular one, based on our experience, we recommend the primary use of circular incision.

In conclusion, anamnesis and physical examination are the main diagnostic tools for penile fracture. When these methods fail to yield definitive diagnosis, cavernosography should be performed in order to confirm the diagnosis. If there is difficulty voiding and/ or urethrorrhagia, retrograde urethrography should be performed in order to visualize the urethral injury. In the treatment of penile fractures, we believe that early surgical repair is the only treatment option for all ruptures, regardless of size.

\section{REFERENCES}

1. Cecchi M, Pagni GL, Ippolito C, Summonti D, Sepich CA, Fiorentini L. Fracture of the penis: description of a case. Arch Ital Urol Androl 1997;69:137-9. [Abstract]

2. Schrama J, Skjetne O, Vada K. Penis fracture. Tidsskr Nor Laegeforen 1998;118:2017-8. [Abstract]

3. Muentener M, Suter S, Hauri D, Sulser T. Long-term experience with surgical and conservative treatment of penile fracture. J Urol 2004;172:576-9.

4. Kowalczyk J, Athens A, Grimaldi A. Penile fracture: an unusual presentation with lacerations of bilateral corpora cavernosa and partial disruption of the urethra. Urology 1994;44:599-601.

5. Nymark J, Kristensen JK. Fracture of the penis with urethral rupture. J Urol 1983;129:147-8.

6. Karadeniz T, Topsakal M, Ariman A, Erton H, Basak D. Penile fracture: differential diagnosis, management and outcome. Br J Urol 1996;77:279-81.

7. Mydlo JH, Harris CF, Brown JG. Blunt, penetrating and ischemic injuries to the penis. J Urol 2002;168:1433-5.

8. Mc Aninc JW, Santucci RA. Genitourınary trauma: In: Walsh PC, Retik AB, Vaughan E D, Wein AJ, editors. Campbell's Urology. 8th ed. Philadelphia: Saunders; 2004. p. 3707-40.

9. El-Bahnasawy MS, Gomha MA. Penile fractures: the successful outcome of immediate surgical intervention. Int J Impot Res 2000;12:273-7.

10. Tsang T, Demby AM. Penile fracture with urethral injury. J Urol 1992;147:466-8.

11. Zargooshi J. Penile fracture in Kermanshah, Iran: report of 172 cases. J Urol 2000;164:364-6.

12. Ozen HA, Erkan I, Alkibay T, Kendi S, Remzi D. Fracture of the penis and long-term results of surgical treatment. Br J Urol 1986;58:551-2.

13. Asgari MA, Hosseini SY, Safarinejad MR, Samadzadeh B, Bardideh AR. Penile fractures: evaluation, therapeutic approaches and long-term results. J Urol 1996;155:149.

14. el-Sherif AE, Dauleh M, Allowneh N, Vijayan P. Management of fracture of the penis in Qatar. Br J Urol 1991;68:6225.

15. Dever DP, Saraf PG, Catanese RP, Feinstein MJ, Davis RS. Penile fracture: operative management and cavernosography. Urology 1983;22:394-6.

16. Mydlo JH. Surgeon experience with penile fracture. J Urol 2001;166:526-9.

17. Mydlo JH, Gershbein AB, Macchia RJ. Nonoperative treatment of patients with presumed penile fracture. J Urol 2001;165:424-5. 